Review

\title{
Minoan and Etruscan Hydro-Technologies
}

\author{
Andreas N. Angelakis ${ }^{1}$, Giovanni De Feo ${ }^{2, *}$, Pietro Laureano ${ }^{3}$ and Anastasia Zourou ${ }^{4}$ \\ 1 Institute of Iraklio, National Agricultural Research Foundation (N.AG.RE.F.), Iraklio 71110 , \\ Greece; E-Mail: info@a-angelakis.gr \\ 2 Department of Industrial Engineering, University of Salerno, via Ponte don Melillo, \\ Fisciano (SA) 84084, Italy \\ 3 IPOGEA, Via Roma 595, Bagno a Ripoli Firenze 50012, Italy; E-Mail: ipogea@ipogea.org \\ 4 Cultural Association Ithaki, Rome 00040, Italy; E-Mail: anastasia.zourou@tiscali.it \\ * Author to whom correspondence should be addressed; E-Mail: g.defeo@unisa.it; \\ Tel.: +39-089-964-113; Fax: +39-089-968-738.
}

Received: 25 April 2013; in revised form: 5 June 2013 / Accepted: 28 June 2013 /

Published: 8 July 2013

\begin{abstract}
The aim of this study is to present water and wastewater technologies used during the Minoan (ca. 3200-1100 BC) and Etruscan (ca. 800-100 BC) civilizations. The basic technologies considered are: water harvesting and distribution systems, cisterns, groundwater and wells as well as drainage and sewerage systems. Minoan water collection and distribution systems primarily consisted of cisterns and pipes. The Etruscans' hydro-technology also consisted of cisterns and pipes but was developed for urban areas and included distinctions between public and private water use. The long-term sustainability of Minoan cisterns is evidenced by the fact that this technique is still practiced today in rural areas of Crete. In addition to cisterns, wells have been used in Crete since Neolithic times, and enjoyed wide-spread use during the Etruscan era. All the Minoan palaces applied strategies to dispose of water and wastewater with open terracotta or stone masonry-conduits, and stone masonry sewers; while, the drainage and sewerage systems developed by the Etruscans were based both on a coordinated and comprehensive planning of the slopes of drainage channels on the sides of streets as well as on a massive use of drainage tunnels.
\end{abstract}

Keywords: cisterns; drainage and sewerage systems; Etruscan; Minoan; water distribution systems; water harvesting; water supply; wastewater; wells 


\section{Introduction}

The hydro-technological achievements of the 21 st century have elicited disdain from some contemporary engineers compared to the hydro-technological achievements of the past. However, as water management issues continue to be confronted globally, some contemporary engineers have investigated hydro-technologies of the past. Modern engineers have found similarities between ancient and modern hydraulic engineering principles and have marveled at the advanced levels of water engineering and management practiced by ancient civilizations [1-3]. In the past, technological developments were catalyzed by the need to efficiently use natural water resources in order to improve resistance against destructive natural elements, and improve quality of life: Minoan and Etruscan civilizations offer valuable paradigmatic case studies.

The history of Greece begins with the Minoan Era (ca. 3200-1100 BC). Minoans were an ancient civilization on what is now Crete (in the Mediterranean) during the Bronze Age and were unlike any that preceded or followed. Unlike the Mycenaeans and the later Greeks, the Minoans saw themselves as harmonizing with the natural world [4]. The organic quality of Minoan architecture is seen most clearly in the palaces of Crete. The four major palaces at Knossos, Phaistos, Mallia, and Zakros, all followed the same basic plan [5]. The private houses of Minoan Crete ranged from simple peasant dwellings to rich mansions and villas, constructed with the same features and techniques as the palaces. The most remarkable part of the palaces is their impressive technology since apartments were equipped with running water and the equivalent of flushing toilets [6].

Although very little is known about the origin of the first settlers in prehistoric Crete, the existence of pottery technology and various artifacts, suggest their possible origin from Anatolia (Egypt) rather than from mainland Greece [7]. The population of Crete was reinforced at the beginning of the Minoan period, e.g., immediately after ca. $3000 \mathrm{BC}$, with the arrival of new settlers, probably from Asia Minor [6]. Furthermore, linguistic affinities have been identified between the Minoans and the Cretan population, which during the mid to late Minoan period, settled in Asia Minor [8]. The Minoans were primarily a mercantile nation engaged in overseas trade. The Minoans managed a lucrative ancient shipping empire that dominated the Mediterranean, Greece, the Greek Islands, and stretched as far as east as the Black Sea. Thus, Minoan contact with other pre-historical civilizations (e.g., located elsewhere in the Mediterranean, as well as Europeans, and Asians) has been documented [9].

The Etruscans ( $c a$. 800-100 BC) settled along Italy's Mediterranean coastal regions of Tuscany, Umbria and Latium, with branches reaching as far south as the Italian Campania. Since the Etruscans were engaged in agriculture and animal husbandry, they developed drainage and channelization works. The Etruscan civilization is celebrated for their construction techniques as well as artwork production, as evidenced by surviving grave frescos. The Etruscan civilization achieved its zenith around the 7th century $\mathrm{BC}$ during which time they were actively trading with Rome during the monarchy period $[10,11]$.

Comparing and analyzing Minoan and Etruscan water systems allows modern engineers to indirectly obtain useful information about these two civilizations. Both civilizations are closely connected with the research and excavation of Bronze Age (the Minoans) and Iron Age (the Etruscans) metals. Therefore, both civilizations had to deal with two similar issues: (a) the ability to excavate and construct underground structures; and (b) the need to settle in certain areas-whether determined by 
the presence of metals or for defensive reasons - where there may have been limited supplies of other natural resources, including water [12].

The aim of this study is to discuss the main concept of water and wastewater developments during the Minoan ( $c a$. 3200-1100 BC) and Etruscan (ca. 800-100 BC) civilizations with some conclusive remarks emphasizing the differences and similarities between them. The basic technologies considered are: water collection and distribution systems, cisterns, groundwater and wells and, finally, drainage and sewerage systems (other technologies such as aqueducts, fountains and irrigation systems have not been considered due to space limitations).

\section{Possible Links between Minoans, Mycenaeans and Etruscans}

During circa $1450 \mathrm{BC}$, a disaster laid waste to all the centers of Minoan Crete. Although the cause of the disaster is unknown-e.g., earthquake, revolution, or invasion - it is known that new rulers appeared in the Aegean at that time. Meanwhile, the Minoan civilization was overrun by the Mycenaean civilization from mainland Greece. Thus, the advanced Minoan hydro-technologies spread to the Greek mainland [6]. Crete however did not utterly collapse, and approximately 200 years later, according to Homer, it participated in the Trojan campaign with a force of 80 ships (Iliad 1652); while the Mycenaean navy consisted of 100. This could demonstrate some kind of reconstruction of Cretan societies, under the dominance of the Mycenaean kingdoms (ca. 1900-1100 BC). In about 1100 BC the Dorians captured the Minoan strongholds and destroyed the Mycenaean state. Crete then came under the control of the conquering Dorians and ended the Bronze age ( $c a .1400 \mathrm{BC}$ to $1100 \mathrm{BC}$ ) [6]. Notably, the influence of Minoan culture and technology and trade relationships extended beyond the borders of the Cretan island to Cyprus, Egypt and Anatolia. Contact between Minoans and other pre-historic civilizations (e.g., Europeans, Asians, and even North Americans) has been documented [9]. The Cretans were celebrated for their naval fleet, their pottery, and their palaces and villas [13]. As a consequence of the close geographical proximity and commercial trade routes between east and west, Minoan technology exhibited orientalizing trends.

Due to the presence of rough and rocky soils and the absence of abundant groundwater in Crete and the Greek islands, the Minoans were obliged to use surface water, drain water from natural caves and cavities, and store water in cisterns and underground tanks. These practices are part of a spiritual conception where underground worlds and water processes (water ascends from the bowels of the earth into the highest atmosphere and vice versa) are metaphors for human destiny [12,14]. Similarly, drainages, meanders and mazes are part of the heritage of symbols and water practices of the Etruscan civilization which settled in central and southern Italy from pre-historic times to Roman antiquity. To permit agricultural activity in northern Latium and Tuscany, the soils were drained by means of moats, tunnels, dams and diversion systems similar to those realized in Boeotia in the second millennium to control the level of Lake Copaide [14]. Arguably, the Minoans and other prehistoric peoples of Greece introduced hydro-technologies to central Greece [6].

During the Early Iron Age ( $c a .1100-950$ BC), aqueducts, cisterns, and wells were built similarly to those constructed by the Minoans and Mycenaeans. A period of prosperity ( $c a$. 7th century BC) occurred when trade flourished and Cretan colonies reached as far as Marseille, France, and Cyrene, Libya; simultaneously, Sicily and central Italy experienced two centuries of economic distress [13]. 
Thus, the art of Doric Crete exhibits orientalizing trends even during the "Geometric" period, possibly due to the island's close geographic proximity and commercial ties between east and west.

In addition, the pre-Etruscan history of the area in the late Bronze and early Iron Ages parallels that of the early Greeks. The Tuscan region of Italy was inhabited by peoples of the so-called Apennine culture in the late second millennium BC ( $c$. 1350-1100 BC) who had trading relationships with the Minoan and Mycenaean civilizations. Subsequently, city-states developed in the late Villanovan culture (ca. 1100-700 BC) in Tuscany and Etruria (paralleling Greece and the Aegean) before "Orientalization" occurred and the Etruscan civilization developed. Arguably, cultural and technological interconnectedness existed between Minoans, Egyptians, Mycenaeans, pre-Etruscans, and post Minoans.

Etruscan fortified cities such as Orvieto, Orte and Volterra had stairs carved into the rock, as well as cisterns and tunnels similar to those found in Mycenaean citadels. The technique of water drainage with underground tunnels, the so-called "qanat" in Iran, may have been exported into Italy from the East in the 8th century by the Etruscans through Lydia. However, the theory that Etruscan emigrated from Lydia to Italy in the 8th century BC is not accepted by archaeologists [15]. Rupestrian works, crevices in the rock (the so-called Etruscan cut), and underground meanders used with a votive purpose also had water functionality. The common need to control the water cycle from the atmosphere to the underground characterizes both Minoan and Etruscan civilizations and underscores hydro-technological similarities [12,14,16].

\section{Water Harvesting and Distribution Systems}

During the Minoan Era, pipes were used for distributing and collecting water. Several terracotta pipes were developed by the Minoans [17]. Occasionally, however, stormwater was conveyed by terracotta pipes, instead of spring water. In a case from Myrtos-Pyrgos (west of the city of Ierapetra) a terracotta pipe of rectangular shape supplied the nearby cistern system with stormwater collected from roofs (Figure 1a).

Figure 1. Minoan water distribution projects: pipes of rectangular shape from Myrtos-Pyrgos (a) and closed terracotta pipes at Knossos palace (b).

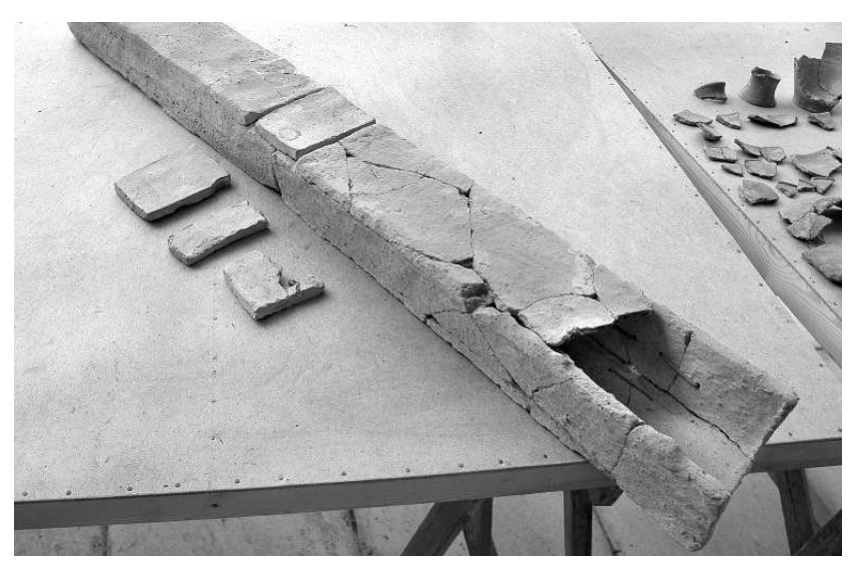

(a)

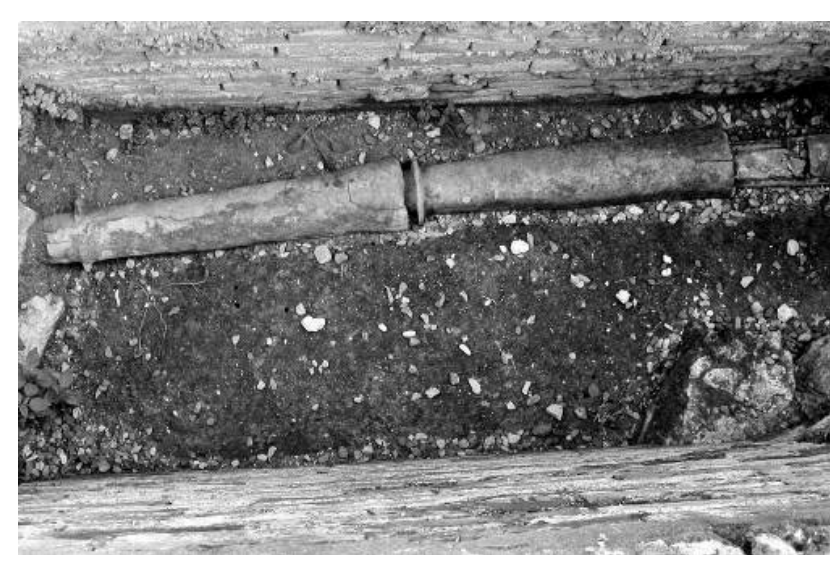

(b)

In Minoan Crete, the technology of transporting water with the use of aqueducts was highly developed due to the island's mountainous terrain. Water was mainly conveyed or channeled from 
areas rich in spring water. For example, the main source of water supply at the palace of Knossos, initially, was the spring of Mavrokolymbos, a pure limestone spring located approximately $500 \mathrm{~m}$ southwest of the palace $[5,18]$. Water was conveyed to Knossos from as far as the mountainous area of Juctas, located approximately $10 \mathrm{~km}$ away. Minoan aqueducts were of two basic types: the open/natural gravity flow system (e.g., Malia and Tylissos); and the closed/pressured pipe system (e.g., Knossos). The closed system implies a practical knowledge of the hydraulic principle that water seeks its own level. Based on certain pipes found at the Guest House (Caravanserai) south of the palace at Knossos, it has been suggested that the latter was supplied with water from the spring located in the low hill at Gypsades $[5,18,19]$. The water first descended and then ascended through a bridge with an estimated inclination rate of 5\% suggesting an application of the principle of communicating vessels. If this was the case, then it is possible to infer that Minoan master craftsmen were aware of several hydraulic principles (e.g., siphon and communicating vessels).

The Minoan distribution systems appear to have served public water supply networks. They fed a public fountain or an open area from a spring, as shown in the case of the town of Zakro. Two handmade tubes about $30 \mathrm{~cm}$ long with a narrow opening on a zoomorphic side were found in a building. The other side is open with traces of plaster (indicative of its incorporation on a built wall). The artifacts are dated before the end of the Late period (ca. 1450 BC) [20]. Several different types of conduits were found in archaeological excavations in Crete belonging to the Minoan Era. They were used for water supply as well as for stormwater and wastewater removal and are made of stone or terracotta [17]. Moreover, physical evidence suggests that the pipes probably fed fountains in open areas of the palaces and were not part of a domestic distribution system, as most scholars have advocated [20]. The advanced urban water distribution system of the closed type in the Minoan palaces and settlements, merits further analysis. The evidence for closed type water distribution in Minoan Crete originates from the use of terracotta pipes (Figure 1b), found at the palaces of Knossos and Tylissos, along with several others, discovered at the palace of Phaistos and at Palaikastro, Gournia, Lykastos and Zakro (House B). Among them, the best preserved examples are from the palace at Knossos, belonging to the earliest middle period and at Tylissos, assigned to the earliest Late period (ca. 1700-1100 BC) although an earlier date has also been proposed for it [7]. Most of the best examples of the pipe system were found in the area of Knossian influence in north-central Crete; it may be argued that this water supply technique was introduced for the first time in this particular region of the island [5]. It should be noted that, since the volume carried by the pipes is limited, these aqueducts were auxiliary. Alternatively, others pipes made of cypress, which was found in abundance in this region, may have been used.

Remains of the Etruscan water collection and distribution systems have been found in several Central Italian cities such as Perugia, Orvieto, Todi, and Marzabotto. The urban plan of an Etruscan city, perfectly organized in terms of both viability and discrete public and private spaces, was characterized by a complex and efficient water system consisting of channeling for rainwater, and cisterns and wells for the collection of spring water for private houses and public facilities, as well as a road network. The archaeological site in the city of Marzabotto (Figure 2a), in the Province of Bologna, in Central Italy, is particularly interesting. The ancient site of Marzabotto was very well organized in terms of water collection and distribution and, evidenced a unique hydraulic system (Figure 2b). 
The system was excavated between 1870 and 1872. The plant was found at a depth of about $4.50 \mathrm{~m}$. The structure was placed on the ground, not far from its original site. The plant, constructed of travertine blocks, consists of a partially-exposed central body of $1.80 \times 1.20 \mathrm{~m}^{2}$ (exterior) by $1.45 \times 0.65 \mathrm{~m}^{2}$ (interior), divided by a sort of diaphragm into two tanks of different levels. The overall height is approximately $0.50 \mathrm{~m}$. Two upstream channels intercepted the water of superficial groundwater. The water entered in the first of the two tanks, a settling tank of $0.75 \times 0.65 \mathrm{~m}^{2}$ with a height of $0.50 \mathrm{~m}$. This tank could contain approximately $244 \mathrm{~L}$ of water. The impurities were deposited on the bottom of the first tank, while the clean water was channeled toward the underlying urban area by two travertine ducts. Both the outflow travertine channels consist of a double row of blocks with an interior opening measuring approximately $14 \mathrm{~cm}$ in diameter. The channels were directed towards two important workshops for the production of ceramics and bricks [21]. Notably, similar channels had been developed in Greece during the Hellenistic period [1].

Figure 2. Etruscan archaeological site of Marzabotto, Central Italy: general view (a) and collection and distribution system originally found at a depth of about $4.50 \mathrm{~m} \mathrm{(b)}$.

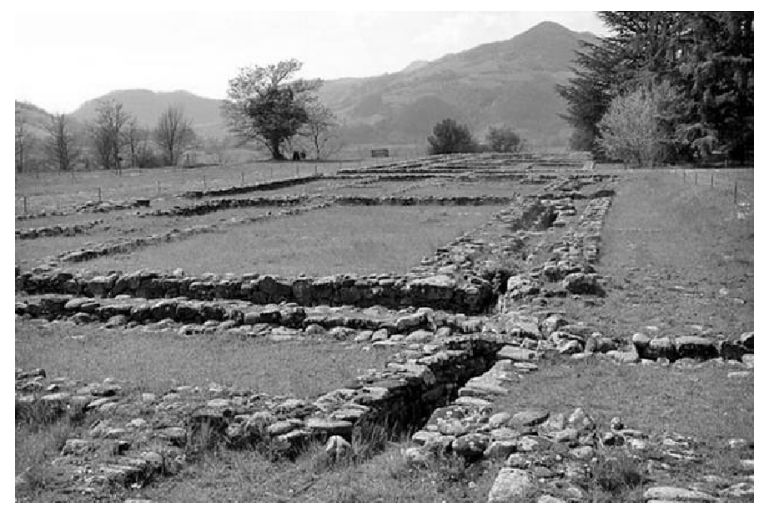

(a)

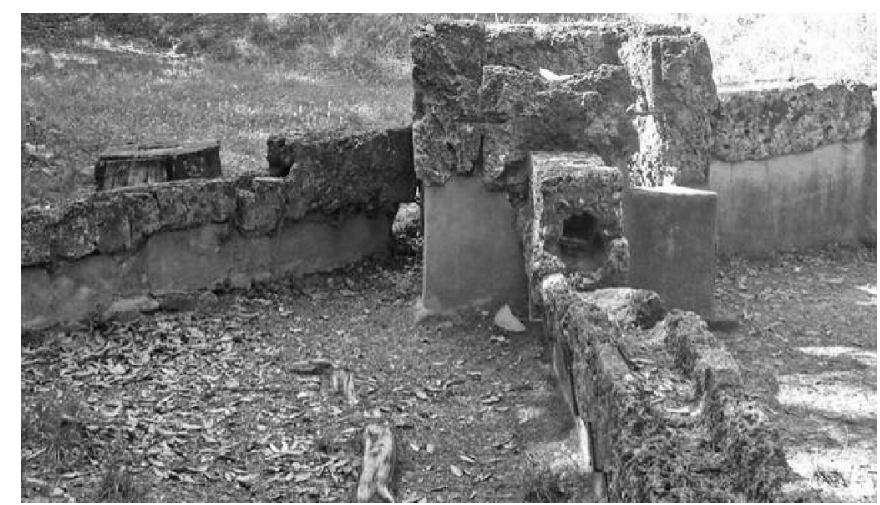

(b)

\section{Cisterns}

It contrast to other ancient civilizations (e.g., Egyptians, Mesopotamians, and Indus) which developed in regions with high water availability, all major Greek cities were established in places with low water availability. In Minoan Crete, it can be argued that the traditional criteria for selecting new settlements were military defensiveness, abundance of food, the climate and health. Dry climates are generally more convenient and healthier as they protect resident populations from water-related diseases. Thus, the technology of storage of surface runoff rainwater as well as that of transporting water by aqueducts was advanced. Water was conveyed into cisterns, a technique still practiced today in rural areas of the island [5]. One of the earliest pre-historic cisterns on the island was discovered in the centre of a pre-palatial house complex on a hill at Chamaizi which is datable to the early-middle Minoan period in the closing years of the third and the dawning of the second millennium BC [22]. From the period of the Minoan palaces (middle-late) four cisterns have been identified at Myrtos-Pyrgos, Archanes, Zakros. At Myrtos-Pyrgos, two cisterns were found, one on the top of the hill where the settlement lies and the other on its slope [23]. The latter is the larger, with a diameter of $5.3 \mathrm{~m}$ and a depth of more than $3 \mathrm{~m}$. Both cisterns have a capacity of more than $80 \mathrm{~m}^{3}$ and date to the middle 
period ( $c a .1700 \mathrm{BC}$ ), corresponding with the last phase of the existence of the First Minoan palaces which are also dated $c a$. 1900-1700 BC In the Zakros palace, on the side of the Central Court, across the so-called "King's Apartment", a colonnade with a central pillar on a high base was located, while on the eastern side a large wooden pier-and-door partition system led into the spacious rectangular "Hall of the Cistern". In its centre, a circular cistern below the ground level was found [5,6,24]. Two similar cisterns have been also found at Archanes-Tourkoyeitonia [24] and Zakro [24].

Unlike the cistern of Myrtos-Pyrgos (Figure 3a), that of the second palaces were built after the catastrophic earthquakes of $c a .1700 \mathrm{BC}$, destroyed the first palace construction campaign. Both date to a middle late period ( $c a .1500 \mathrm{BC}$ ) and are of similar cylindrical shape [25]. A cistern belonging to the post palatial Era is that of Tylissos dating to $c a$. 1330-1200 BC [26]. This cylindrical-shaped cistern (Figure $3 b$ ) was located at the northern site of the House $C$ and was considered a part of the aqueduct. Its size and shape recall the earlier examples from Zakro and Archanes with their similar steps and plastered walls [5].

Figure 3. Minoan cisterns: at Myrtos-Pyrgos in the S.E. Crete (a) and at Tylissos Houses (b).

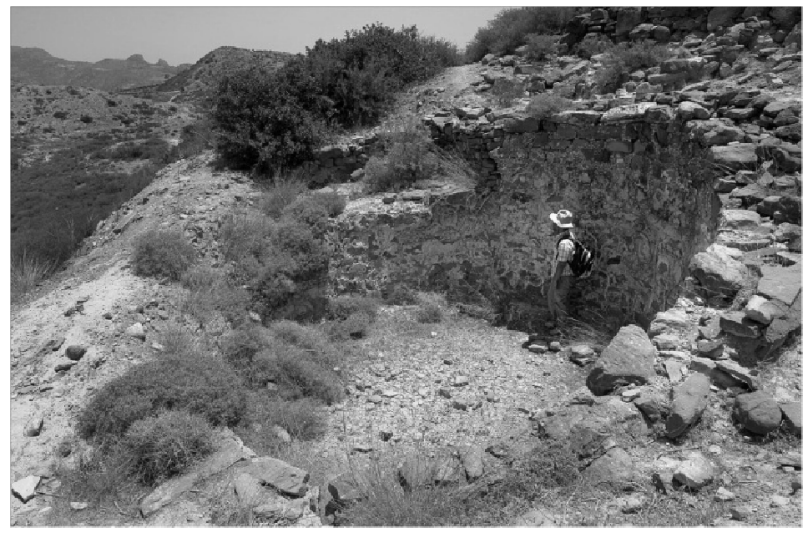

(a)

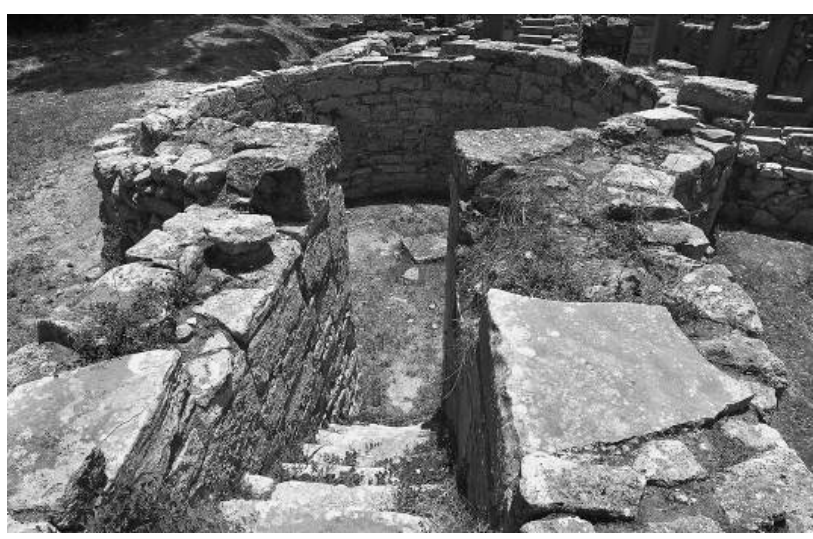

(b)

The city of Perugia, in Umbria, is full of ancient Etruscan wells and cisterns. They are related to each other on the basis of a path linked to the old street network based on orthogonal axes, connected to the main gates of the city. One of the most interesting cisterns is in Via Cesare Caporali, accidentally discovered in 1989 during renovations of a building (Figure 4a). The cistern is $8 \mathrm{~m}$ under the level of the roof slab. The walls are constructed of stones and mortar, and coated with watertight plaster. The vertical wall featured a hole of about $6 \times 10 \mathrm{~cm}^{2}$ in order to intercept the groundwater. Two terracotta channels are located at the top, almost diametrically opposite, for collecting and conveying rainwater into the cistern. The plan at the bottom of the cistern is in opus signinum. The top diameter is $3.64 \mathrm{~m}$, while the bottom is $2.98 \mathrm{~m}$. The bottom plane is inclined towards a collection sump consisting of a travertine block. The cover of the cistern consists of large travertine slabs partially resting on the edges of the reservoir as well as two beams parallel to the diameter of the mouth, which divide the cistern into three spaces. The cover structure behaves statically as a wooden structure, similar to that used for the Sorbello's well, still present in Perugia and described below [27]. In 1888, in Orvieto, in Umbria, the so-called Etruscan cistern of San Domenico was discovered. The cistern, which is well preserved, is covered with a layer of clay measuring $50 \mathrm{~cm}$ in depth. It has a cylindrical section slightly tapered towards the bottom, with a diameter greater than $2.90 \mathrm{~m}$ and a height of $5.10 \mathrm{~m}$. 
The lateral surface of the cistern is made from tufa, travertine and basalt. The floor consists of crushed tufa with an underlying thin layer of sand overlaid on a thick layer of clay that surrounds the entire structure. The cover is made from blocks of tufa [28]. In the town of Todi, also in Umbria, there are about $5 \mathrm{~km}$ of hypogeum tunnels and galleries, more than 30 cisterns, dating from the Etruscan, Roman and medieval periods, and approximately 500 wells (Figure $4 \mathrm{~b}$ ). Particularly interesting is the so-called forensic Etruscan cistern ("Cisterna Forense"). The cistern rests on a base of about $2 \mathrm{~m}$ in opus caementicium on which the perimeter walls and partitions between the nine adjoining rooms, all built in opus caementicium, are placed. The barrel vaults were constructed on the walls and partitions (all of opus caementicium) by means of wooden ribbing, following well tested Etruscan craftsmanship. Overall, the tank is about $37 \mathrm{~m}$ long and $8.1 \mathrm{~m}$ wide [29].

Figure 4. Plant of the cistern in Via Cesare Caporali, Perugia, central Italy (a) [27]; and Tunnels and galleries, more than 30 cisterns, Etruscan, Roman and Medieval and about 500 wells of several ages in the city of Todi, Umbria (b).

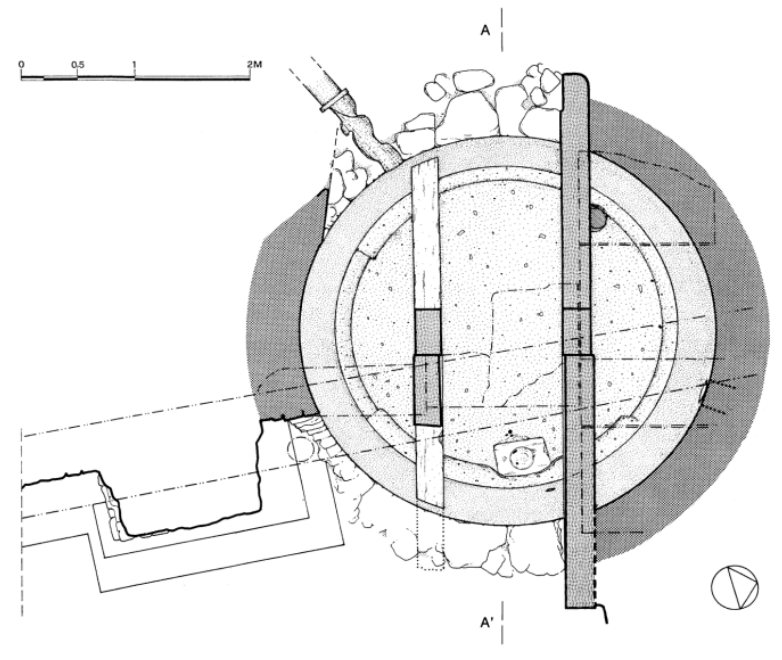

(a)

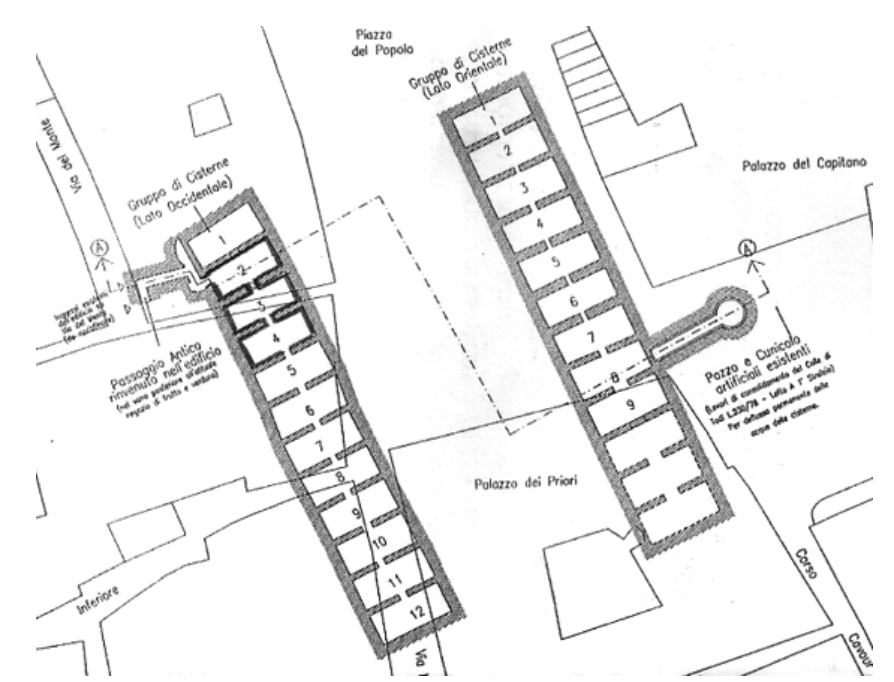

(b)

\section{Groundwater and Wells}

The water supply in several Minoan settlements in the eastern part of Crete depended on groundwater. In the Zakros palace, potable water came from a chamber with a well-spring located in the southeast part of the Central Court. Several steps lead down into the well. The water supply in the Minoan town of Palaikastro also depended on groundwater where several wells have been discovered with depths ranging from 10 to $15 \mathrm{~m}$ [5]. One example is illustrated in Figure 5a. The sites of Palaikastro and Zakros are situated in the eastern part of the island which in antiquity appears to have been exceptionally rich in groundwater; today, however, its water is saline. In addition to the wells in Palaikastro and Zakros at least six wells have been reported from the area of the palace in Knossos dating from the period of the First palaces (ca. 1900-1700 BC) [19]. In Palaikastro, several wells were used for drawing drinking water, but their date is uncertain. The ready access to cool and fresh water that wells alone could supply, made their construction highly desirable and they were used along with the other sources of water previously described. 
Etruscan wells for water supply were everywhere in the ancient urban area of Marzabotto: in practice almost each house had one well. The structure of the wells was based on a coating of pebbles. Shape and depth varied with static problems and soil characteristics and with depth of groundwater in the city's plateau. The end part of each well, dug into impermeable marl, was used as a water storage tank in order to guarantee the availability of water even in times of drought when the water table was lowered to the boundary of river gravel. The well often had a gradual expansion in the soil until reaching the impermeable marl layer where the storage tank was constructed. The obliquity of the walls depended on the surrounding soil consistency as well as the wells depth. For instance, the cylindrical wells were generally the deepest [21]. Ancient Perugia, as noted above, was rich in both wells and cisterns. The so-called "Pozzo Sorbello" (Sorbello's Well), is considered the most important monument of the water supply system of Perugia [27]. The well is located in the highest part of the city. It was dug in the conglomerate, reaching a depth of approximately $36 \mathrm{~m}$ from the road surface. The cavity has a diameter of $5.6 \mathrm{~m}$ and a height of $12 \mathrm{~m}$ [30]. In Piazza IV Novembre, in Perugia, next to the Fontana Maggiore (the most significant medieval monument for the city's water supply), where the ancient forensic area is traditionally located, there is the so-called "Pozzo della Piazza" (Square's Well). The diameter of the well varies between 3.2 and $3.5 \mathrm{~m}$, it is more than $47 \mathrm{~m}$ deep and the top is covered with irregular pieces of travertine. At the foot of the forensic area, near Piazza F. Cavallotti, inside the building of the cathedral chapter, there is another well with a diameter of $1.2 \mathrm{~m}$, it has only the upper part of the cane dug in the ground filling and is covered with irregular stones, while the section below is dug directly into the so-called "tassello", a lacustrine conglomerate which constitutes the local bedrock $[27,31,32]$.

Figure 5. Minoan well used for water supply at Palaikastro city, eastern Crete (a) and Well at the location Campetti, Etruscan City of Veio north of Rome (b).

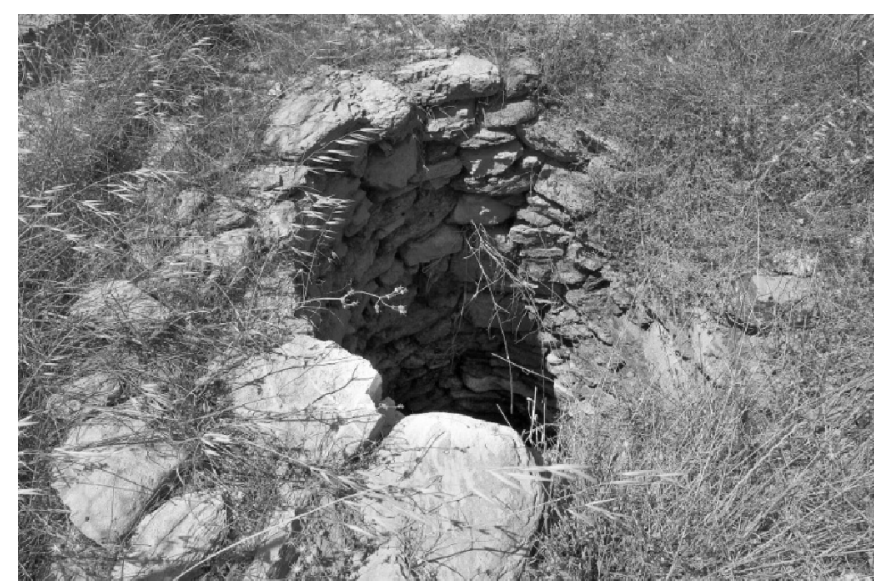

(a)

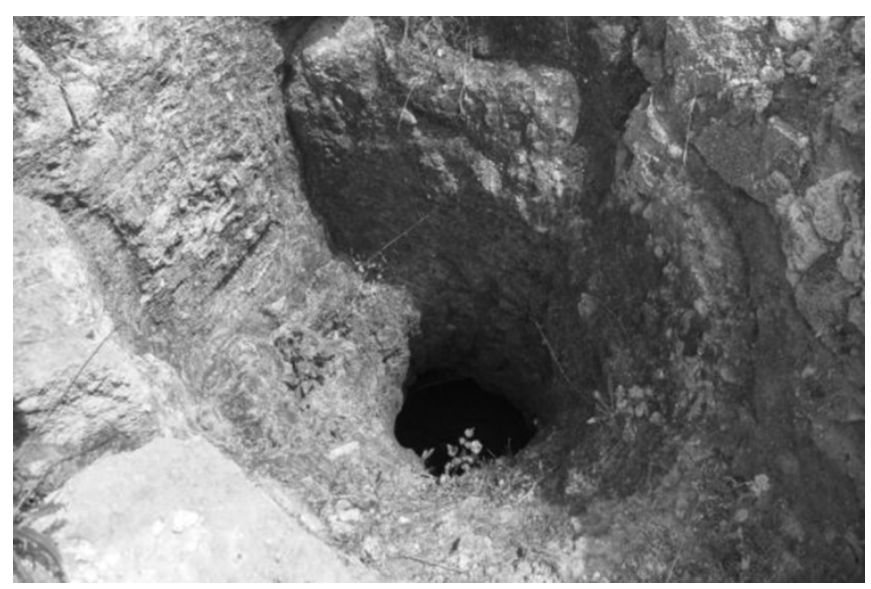

(b)

In addition, the Etruscan town of Veio, a few kilometers away from Rome, was one of the most remarkable examples of diverse hydraulic works including groundwater wells (Figure 5b). The town had a huge network of underground aqueducts, $50 \mathrm{~km}$ of which still remain, all realized between the ninth and the fifth century BC The aqueducts were used to monitor water capacity during floods, and to minutely and harmonically distribute water during droughts, through a complex system of flood-gates, tunnels, barrages, artificial lakes, and wells [33]. 


\section{Drainage and Sewerage Systems}

Evans (1921-1935) [19] and MacDonald and Driessen [34], described the state of sewerage in the Minoan palace of Knossos and provided a plan of the original form. The total extent of the system, including secondary pipelines and drains exceeds $150 \mathrm{~m}$.

The best-explored part of the drainage and sewerage system lies beneath the formerly populated portions of the palace. The system consists of one big loop with the highest point at a light well near the grand staircase, discharging through a connected conduit that follows the slope to the east of the palace [19]. In the departments of "Hall of the Double Axes" and "Hall Queen" with the side apartments, the sewage was discharged through at least five light wells. The wastewater of the so-called Queen's toilets was discharged through the same system. The system drains also included rainwater from the roof, which may have been connected with toilets on the upper floors. The main dimensions are $79 \times 38 \mathrm{~cm}^{2}$, made of stone and plastered with mortar. The sewers, then, were large enough to permit men to enter them for cleaning or maintenance; in fact, manholes were provided for this purpose [6]. Finally, there were openings located at intervals for ventilation [35]. These large sewers may have inspired the genesis of the labyrinth, the subterranean structure in the form of a maze that hosted the Minotaur, a hybrid monster. Remains of central sewerage and drainage systems of stone from the palaces of Phaistos and Knossos are shown in Figure 6.

Figure 6. Minoan central sewerage and drainage systems: at palace of Phaistos (a) and at palace of Knossos (b).

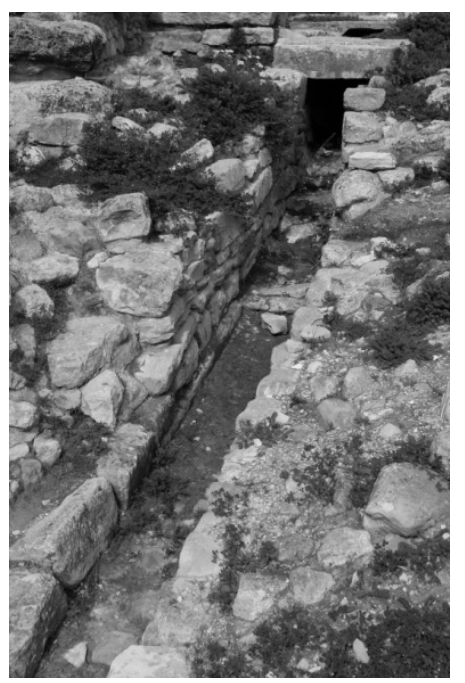

(a)

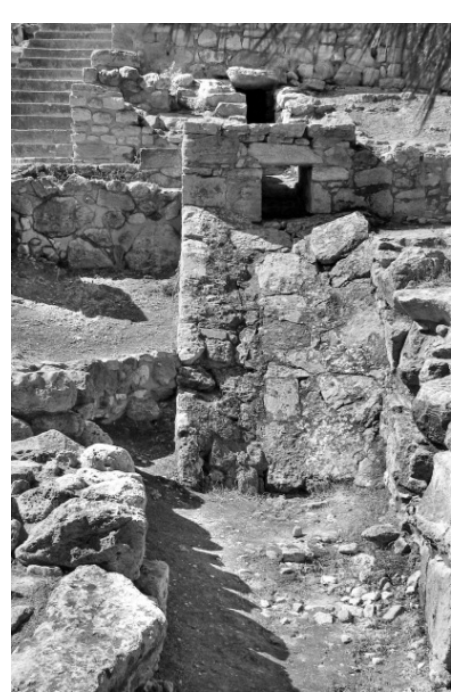

(b)

All the central sewers were located beneath the streets (e.g., Knossos and Phaistos) where drainage systems were situated on both sides of the streets and stairs. A good paradigm is the ancient road in Knossos known as the "oldest road in Europe" which connects the palace (Theatre area), the House of Frescos, and the Little palace. It is paved with stone slabs and cement wings with drains are located on either side [36]. In addition to sewerage and drainage systems, some palaces had toilets with flushing systems operated by pouring water into a conduit [5,37]. However, the best example of such an installation was found in the Cycladic island of Thera (modern Santorini) [38]. This is the most refined 
and best-preserved pattern belonging to the late ( $c a .1550 \mathrm{BC}$ ) Bronze Age settlement of Akrotiri, which shares identical cultural characteristics with Crete [6].

According to Sassatelli [21] in ancient Marzabotto there featured a coordinated and comprehensive plan of the slopes of drainage channels on the sides of streets. The system was based both on the natural slope of the plateau and on an artificial modification aimed at taking into account the special needs associated with water runoff, such as the need to avoid one of the two necropoli located between the urban area and the river Reno, where wastewater was commonly discharged. De Marinis [39] describes the drainage and discharge systems of the ancient Forcello, in the province of Mantova, in the Lombardy region, assuming the existence of two drains with the main function of town sewer as well as assuring drainage of the entire residential area. The city of Perugia is rich in drainage tunnels (the so-called "cuniculi", plural, or "cuniculus", singular). The tunnels are mostly dug into the natural conglomerate; only a few have been excavated in the fill soil. The cross section is elongated with an ogival vault; they are $1.7-1.8 \mathrm{~m}$ high and $0.7-0.8 \mathrm{~m}$ wide. The cuniculi of Perugia are similar to those of Orvieto and Todi [40]. According to Piro [41] most of the tunnels of Perugia had a drainage function. The tunnels were always placed in contact with conglomeratic and silt-sandy soils or within the thickness of the filling soil. This condition enabled good drainage efficacy . Moreover, draining water improved the geo-mechanical characteristics of the soil and provided more stable soil embankments. The cliff upon which Orvieto stands is composed of a thick layer of tufa alternating with layers of pozzolan. The erosive action of the atmosphere coupled with the anthropic activity shaped the cliffs, making it an impregnable fortress, and the site of an important Etruscan community. In the plateau, isolated on every side, there are more than 600 artificial cavities, in which many Etruscan remains have been found $[42,43]$.

The city of Todi, in Umbria, is located on an isolated hill near the confluence of the Rio stream with the river Tiber. The wells of each Era in the historical center of Todi number more than five hundred, and the network of tunnels, dug at different altitudes, covers planimetrically almost the entire urban area [44]. Bruschetti [29] describes the tunnels of the great bastion system, the so-called "Etruscan bastion". Behind the ramparts, there are several drainage channels. The main tunnel, located on the lower level, was the first constructed to drain water into the ditch. Other tunnels, at higher altitudes, but all converging to the first through a well, drain and convey spring waters and rainwater that otherwise would be dispersed throughout the fill, causing excessive pressure on the retaining wall structure. The tunnels have different sections: in all cases the walls are lined with blocks of limestone arranged in very regular horizontal rows, the bottom consists of travertine slabs or tiles, laid over filling soil. The upper portion of the tunnels are clad with slabs of travertine or with tiles placed to form a gabled roof. Bergamini [45] describes the tunnel known as "Fontana della Rua" (Rua's fountain). This complex of tunnels is arguably the most important of the city's entire water network: it is the longest (about $350 \mathrm{~m}$ ), has a significant water regime, is in excellent condition and has a variety of building types that denote its continued use over time (Figure 7). 
Figure 7. Sections of the "Fontana della Rua" tunnel in Todi, Umbria region [42].
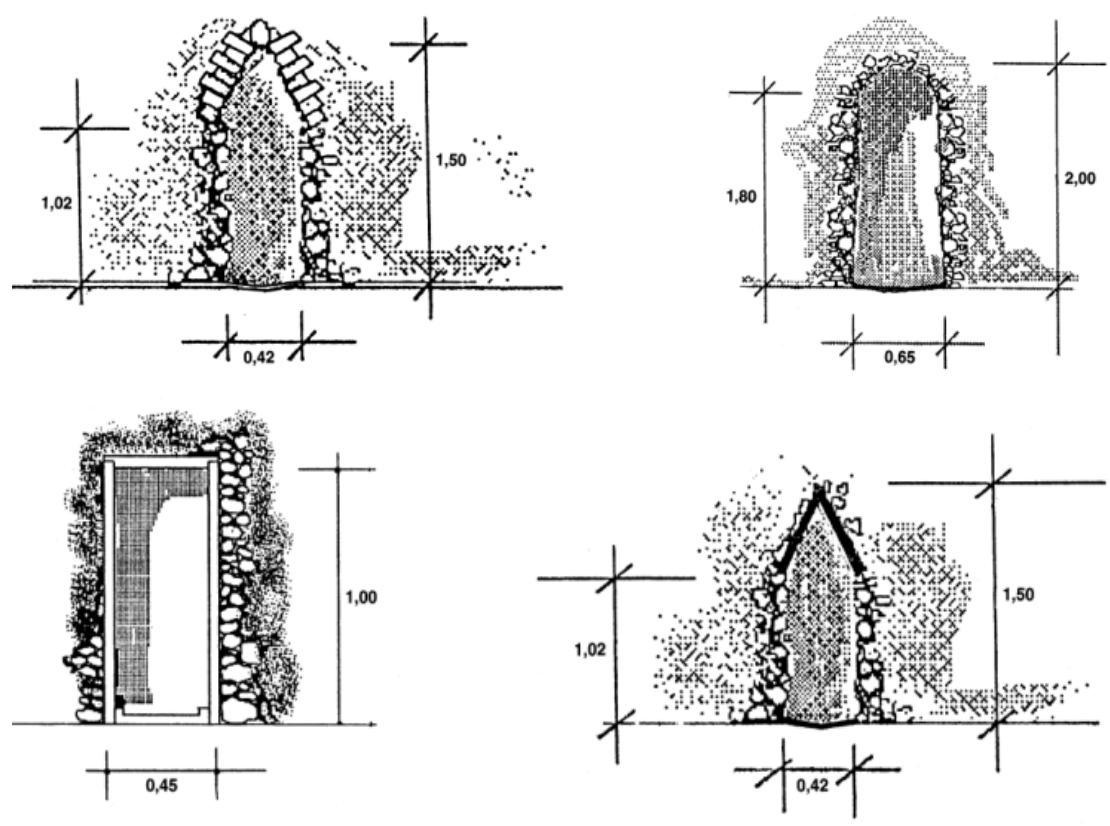

\section{Discussion and Conclusions}

One of the salient characteristics of the Minoan Era in Crete was the architectural and hydraulic function of water supply, sewerage and drainage systems in the palaces and several other settlements. It might be implied, therefore, that Minoan master craftsmen in Bronze Age Crete were aware of some of the basic principles of what modern engineers refer to as water and environmental technologies. Minoan techniques were differentiated according to local conditions and applied to ensure the water supply, including management of spring runoff water, transportation, and storage of water. The first evidence of the use of water and wastewater technologies such as aqueducts, water cisterns, water harvesting and distribution systems, as well as sewerage and drainage systems is in the Minoan Era. However, these technologies were further developed by the Greeks over time, peaking during the Etruscan and Hellenistic periods.

In a broader context, it is important to examine the relevance of ancient water and wastewater technologies to those of the 21 st century. One important question to ask is whether water and wastewater technologies can be traced directly to the Minoans and other ancient civilizations, or whether the technical achievements of the ancients were totally forgotten (during the so-called Dark Ages) and subsequently re-invented [1]. The development of water science and engineering is not linear but often characterized by discontinuities and regressions. Many historians and archaeologists believe that the Minoans, by means of their Mediterranean naval fleet and commercial trade networks, were involved in the Bronze Age's tin trade (tin being used for manufacture of bronze) $[9,19]$. Thus, Minoans "built bridges" with neighboring civilizations such as the Egyptians, Mycenaeans, and Classical Greeks. Also, such bridge-building occurred between the Etruscans and Dorians as well as with the Classical Greeks. They inherited the Minoan technologies and developed them further mainly by changing their application scale from small to large and implementing them to both urban and rural areas.

Arguably, Etruscans acquired their knowledge from the Greeks, which began during the Greeks' expansion within the western Mediterranean during the 8th-7th century BC, at the onset of the 
Etruscan civilization $[46,47]$. There was a long tradition of water management through tunneling in the ancient Mediterranean [48]. Although there are possible direct links between the art of tunneling in ancient Rome and in Greece, the problem of ancient tunneling in the Mediterranean world remains largely unresolved [49].

The importance of the technological achievements realized by Minoan and Etruscan civilizations is underlined by the existence of two urban management systems developed at two different, but not unrelated, historical moments. In both cases, the idea of an urban management system provided the platform upon which the federal system of the "Hundred cities" of Crete and the "Dodecapolis", the twelve lucumoniae in the Etruscan region, were developed. The federal system encouraged reciprocal (financial, commercial and cultural) growth of cities and increased the wellness, richness and stability of the citizens. These achievements became the heritage of European civilization which is now trying to create the largest federal system yet conceived, called United Europe, where local differences such as religion, language, states rules, and local management habits can enhance diversity and collaboration among diverse European populations.

Ultimately, the following conclusive remarks can be made:

(a) The principal aspect of the Minoan water collection and distribution systems was the use of very sophisticated piped and opened gravity systems; while, the Etruscans developed a rational planning of urban areas with a clear distinction between public and private spaces with specific water systems supplying workshops.

(b) The modernity and sustainability of using cisterns for surface and stormwater storage, highly developed in the Minoan Era, is illustrated by the fact that cisterns are still used today in eastern regions of the island. The Etruscans also exhibited their engineering skills (hydraulic, structural and geotechnical) in the construction of cisterns. Particularly, the Etruscan systems featured statical behavior with a wooden structure, the use of barrel vaults, and wooden ribbing.

(c) Wells were used in eastern Crete from Neolithic times, but they were not as diffused as in the Etruscan area. Wells for water supply were ubiquitous in ancient Etruscan urban areas: often the termini were used as a water storage tank in order to guarantee the availability of water even in times of water scarcity.

(d) All the Minoan palaces applied strategies to dispose of rainwater and wastewater with open terracotta, stone made open conduits and stone built sewers. The drainage and sewerage systems developed by the Etruscans were based on a more advanced planning of the slopes of drainage channels on the sides of streets as well as a massive use of drainage tunnels.

(e) Finally, it should be stated that the Minoans and Etruscans lived in harmony with nature and their environment and their knowledge can play an important role in the sustainable water supply, wastewater, and stormwater management of future cities.

\section{Acknowledgments}

Part of this manuscript has been presented in the IWA Congress \& Exhibition in Busan, Korea, 16-21 September 2012. The Authors wish to thank Meisha Hunter for her English revision to the text, as well as the comments of three anonymous referees. 


\section{Conflict of Interest}

The authors declare no conflict of interest.

\section{References}

1. Koutsoyiannis, D.; Zarkadoulas, N.; Angelakis, A.N.; Tchobanoglous, G. Urban water management in Ancient Greece: Legacies and lessons. ASCE J. Water Resour. Plan. Manag. 2008, 134, 45-54.

2. De Feo, G.; Laureano, P.; Drusiani, R.; Angelakis, A.N. 2010 Water and wastewater management technologies through the centuries. Water Sci. Technol. Water Supply 2010, 10, 337-349.

3. Mays, L.W. Ancient Water Technologies, 1st ed.; Springer: Berlin, Germany, 2010.

4. Lyrintzis, A.G.; Angelakis, A.N. 2006 Is the Labyrinth a Water Catchment Technique? People and Water Management in Minoan Crete. In Proceedings of the 1st IWA International Symposium on Water and Wastewater Technologies in Ancient Civilizations, Iraklio, Greece, 28-30 October 2006; pp. 163-174.

5. Angelakis, A.N.; Dialynas, M.G.; Despotakis, V. Evolution of Water Supply Technologies in Crete, Greece through the Centuries. In Evolution of Water Supply through the Millennia, 1st ed.; Angelakis, A.N., Mays, L.W., Koutsoyiannis, D., Eds.; IWA Publishing: London, UK, 2012; pp. 227-258.

6. Angelakis, A.N.; Spyridakis, S.V. The status of water resources in Minoan times: A preliminary study. In Diachronic Climatic Impacts on Water Resources with Emphasis on Mediterranean Region, 1st ed.; Angelakis, A.N., Issar, A., Eds.; Springer-Verlag: Heidelberg, Germany, 1996; pp. 161-191.

7. Angelakis, A.N.; Koutsoyiannis, D.; Tchobanoglous, G. Urban wastewater and stormwater technologies in ancient Greece. Water Res. 2005, 39, 210-220.

8. Huxley, G. Crete and the Luwians, 1st ed.; Oxford University Press: Oxford, UK, 1961.

9. Mariolakos, I. The Forgotten Geographical and Natural-Oceanographic Knowledge of the Prehistoric Greeks [in Greek]. Available online: http://www.ekke.gr/estia/Cooper/Mariolakos/ New_Mariolakos_greek.pdf (accessed on 21 February 2013).

10. Magagnini, A. Gli Etruschi. Storia e Tesori [in Italian], 1st ed; Edizioni White Star: Vercelli, Italy, 2008.

11. Martini, P.; Drusiani, R. History of the Water Supply of Rome as a Paradigma of Water Services Development in Italic Peninsula. In Proceedings of the 2nd IWA International Symposium on Water and Wastewater Technologies in Ancient Technologies, Bari, Italy, 28-30 May 2009.

12. Laureano, P. The Water Atlas: Traditional Knowledge to Combat Desertification, 1st ed.; Bollati Boringhieri: Turin, Italy, 2001.

13. Markonis, Y.; Angelakis, A.N.; Christy, J.; Koutsoyiannis, D. Climatic Variability and the Evolution of Water Technologies in Crete, Hellas. Water Res. Manag. 2013, submitted.

14. Laureano, P. Giardini di Pietra, I Sassi di Matera e la Civiltà Mediterranea [in Italian], 1st ed.; Bollati Boringhieri: Turin, Italy, 1995.

15. Barker, G.; Rasmussen, T. The Etruscans, 1st ed.; John Wiley and Sons: Hoboken, NJ, USA, 2000.

16. Ravelli, F.; Howarth, P.J. Etruscan Cuniculi: Tunnels for the Collection of Pure Water; Report of International Commission on Irrigation and Drainage: Fort Collins, CO, USA, 1984. 
17. Angelakis, A.N.; Koutsoyiannis, D.; Papanikolaou, P. On the Geometry of the Minoan Water Conduits. In Proceedings of the 3rd IWA International Symposium on Water and Wastewater Technologies in Ancient Civilizations, Istanbul, Turkey, 22-24 March 2012; pp. 172-177.

18. Angelakis, A.N.; Savvakis, Y.M.; Charalampakis, G. Aqueducts during the Minoan Era. Water Sci. Technol. Water Supply 2007, 7, 95-102.

19. Evans, A. The Palace of Minos at Knossos: A Comparative Account of the Successive Stages of the Early Cretan Civilization as Illustrated by the Discoveries, 1st ed.; Macmillan and Co.: London, UK, 1921-1935.

20. Platon, E. Minoan Terracotta Water Spouts [in Greek]. In Proceedings of the 7th International Conference of Cretan Studies, Rethymnon, Greece, 25-29 August 1991; pp. 767-775.

21. Sassatelli, G. Opere Idrauliche Nella Città Etrusca di Marzabotto [in Italian]. In Gli Etruschi Maestri di Idraulica, 1st ed.; Bergamini, M., Ed.; Electa Editori Umbri: Perugia, Italy, 1991; pp. 179-207.

22. Davaras, C. The Oval House at Chamaizi Reconsidered. In Archeologika Analekta Ex Athinon; Athens Annals of Archaeology: Athens, Greece, 1972; Volume 2, pp. 283-288.

23. Cadogan, G. Water management in Minoan Crete, Greece: The two cisterns of one Middle Bronze Age settlement. Water Sci. Technol. Water Supply 2007, 7, 103-112.

24. Platon, N. Zakros: The New Minoan Palace, 1st ed.; The Archaeological Society at Athens: Athens, Greece, 1974.

25. Sakellarakis, Y.; Sapouna-Sakellaraki, E. Archanes: Minoan Crete in a New Light, 1st ed.; Ammos/Eleni Nakou Foundation: Athens, Greece, 1997.

26. Hazzidakis, J. Les Villes Minoennes de Tylissos [in French], 1st ed.; Editons Geuthner: Paris, France, 1934.

27. Feruglio, A.E. Approvvigionamento Idrico Nell'antica Perugia: La Cisterna di via Cesare Caporali [in Italian]. In Gli Etruschi Maestri di Idraulica, 1st ed.; Bergamini, M., Ed.; Electa Ed.: Perugia, Italy, 1991; pp. 217-234.

28. Stopponi, S. La Cisterna di San Domenico ad Orvieto [in Italian]. In Gli Etruschi Maestri di Idraulica, 1st ed.; Bergamini, M., Ed.; Electa Ed.: Perugia, Italy, 1991; pp. 209-216.

29. Bruschetti, P. Uso del Sottosuolo per l'Espansione Urbanistica di Todi: Sistemi Idraulici e Strutturali. I [in Italian]. In Gli Etruschi Maestri di Idraulica, 1st ed.; Bergamini, M., Ed.; Electa Ed.: Perugia, Italy, 1991; pp. 115-135.

30. Stopponi, S. Nuove Osservazioni sul Pozzo Sorbello e sul Suo Inserimento nel Tessuto Urbano di Perugia Antica [in Italian]. In Gli Etruschi Maestri di Idraulica, 1st ed.; Bergamini, M., Ed.; Electa Ed.: Perugia, Italy, 1991; pp. 235-246.

31. Esu, F.; Manfredini, M. La Frana di S. Francesco al Prato in Perugia [in Italian]. Rivista Italiana di Geotecnica 1963, 2, 135-145.

32. Cattuto, C.; Gregori, L. Il Colle di Perugia; Note di Geologia, Idrogeologia e Geomorfologia [in Italian]. Bollettino della Società Geologica Italiana 1988, 107, 131-140.

33. Martini, P.; Drusiani, R. History of the Water Supply of Rome as a Paradigm of Water Services Development in Italy. In Evolution of Water Supply through the Millennia, 1st ed.; Angelakis, A.N., Mays, L.W., Koutsoyiannis, D., Eds.; IWA Publishing: London, UK, 2012; pp. 444-466. 
34. MacDonald, C.F.; Driessen, J.M. The Storm Drains of the East Wing at Knossos. In L'Habitat Egéen Préhistorique; Darcque, P., Treuil, R., Eds.; Bulletin de Correspondance Hellénique: Paris, France, 1990; pp. 141-146.

35. Graham, J.W. The Palaces of Crete; Princeton University Press: City, NJ, USA, 1987.

36. Pendlebury, J.D.S. The Archaeology of Crete, 1st ed.; Methuen: London, UK, 1979.

37. Shaw, J.W. Minoan Architecture: Materials and Techniques. Annuario della Scuola Archeologica di Atene e delle Missioni Italiane in Oriente [in Italian]; Istituto Poligrafico Dello Stato: Rome, Italy, 1973.

38. Palyvou, C. Akrotiri Thera: An Architecture of Affluence 3500 Years Old; INSTAP Academic Press: Philadelphia, PA, USA, 2005.

39. De Marinis, R.C. L'Abitato Etrusco del Forcello: Opera di Difesa e di Drenaggio e Importanza Delle vie di Comunicazione Fluviale [in Italian]. In Gli Etruschi Maestri di Idraulica, 1st ed.; Bergamini, M., Ed.; Electa Ed.: Perugia, Italy, 1991; pp. 75-85.

40. Cenciaioli, L. Cunicoli di Drenaggio a Perugia [in Italian]. In Gli Etruschi Maestri di Idraulica, 1st ed.; Bergamini, M., Ed.; Electa Ed.: Perugia, Italy, 1991; pp. 97-104.

41. Piro, V. I Cunicoli di Drenaggio a Perugia [in Italian]. In Gli Etruschi Maestri di Idraulica, 1st ed.; Bergamini, M., Ed.; Electa Ed.: Perugia, Italy, 1991; pp. 105-113.

42. Bizzarri, C. Cunicoli di Drenaggio ad Orvieto [in Italian]. In Gli Etruschi Maestri di Idraulica, 1st ed.; Bergamini, M., Ed.; Electa Ed.: Perugia, Italy, 1991; pp. 163-167.

43. Cenciaioli, L. Cunicoli di Drenaggio ad Orvieto [in Italian]. In Gli Etruschi Maestri di Idraulica, 1st ed.; Bergamini, M., Ed.; Electa Ed.: Perugia, Italy, 1991; pp. 169-176.

44. Mariani, M. Uso del Sottosuolo per l'Espansione Urbanistica di Todi: Sistemi Idraulici e Strutturali. II [in Italian]. In Gli Etruschi Maestri di Idraulica, 1st ed.; Bergamini, M., Ed.; Electa Ed.: Perugia, Italy, 1991; pp. 137-141.

45. Bergamini, M. Todi: Il Cunicolo "Fontana della Rua" nel Sistema Idraulico Antico [in Italian]. In Gli Etruschi Maestri di Idraulica, 1st ed.; Bergamini, M., Ed.; Electa Ed.: Perugia, Italy, 1991; pp. 143-162.

46. Tsetskhladze, G.R. Greek Colonisation: An Account of Greek Colonies and Other Settlements Overseas, 1st ed.; Brill: Leiden, The Netherlands, 2008; Volume 2.

47. Porciani, L. Mediterranean Identities in the Ancient World. In Representation, Expression and Identity: Interdisciplinary Insights on Multiculturalism, Conflict and Belonging, 1st ed.; Rahimy, T., Eds.; Inter-Disciplinary Press: Oxford, UK, 2009; pp. 233-242.

48. Castellani, V.; Dragoni, W. Opere Idrauliche Ipogee nel Mondo Romano: Origine, Sviluppo e Impatto nel Territorio [in Italian]. L'Universo Istituto Geografico Militare 1989, 2, 100-137.

49. Castellani, V.; Dragoni, W. Ancient tunnels: From Roman outlets back to the early Greek civilization. In Proceedings of 12th International Conference of Speleology, La Chaux-de-Fonds, Switzerland, 12-14 August 1997; Volume 3, pp. 265-268.

(C) 2013 by the authors; licensee MDPI, Basel, Switzerland. This article is an open access article distributed under the terms and conditions of the Creative Commons Attribution license (http://creativecommons.org/licenses/by/3.0/). 